\title{
PENGARUH RESISTANCE BARRIERS DAN FAKTOR DEMOGRAFI TERHADAP RESISTENSI INOVASI MOBILE BANKING DI KOTA MATARAM
}

\author{
Muhtar Ahmad ${ }^{1}$ \\ Dedy Iswanto ${ }^{2}$ \\ Lalu Adi Permadi ${ }^{3}$
}

\begin{abstract}
This study is aimed to examine variables that determine mobile banking resistance among banking customer in Mataram. The study included independent variables to a logistic regression model to predict mobile banking adoption or non-adoption. Referring Theory of Innovation Resistance that proposed by Ram and Sheth's (1989), the study examined the effect of resistance barriers variables i.e. usage barrier, value barrier, risk barrier, tradition barrier and image barrier on mobile banking resistance. In addition, the study examined demographic factors i.e. gender, age, level of education and household income. Total respondents were 234, who were of customers of BRI, BCA and Mandiri in Mataram who use mobile devices (cellular phones, smartphones, tablets). Data were analyzed using Binary Logistic Regression because the dependent variable i.e. mobile banking resistance is measured by a binary scale, 0 for "user" and 1 for "non-user". The results showed that usage barrier, value barrier, and risk barrier had a positive significant effect on mobile banking resistance. Among demographic variables, only gender and age had a significant effect on mobile banking resistance, while household income and level of education had a non-significant effect.
\end{abstract}

Keywords: mobile banking, resistance barriers, innovation resistance, logistic regression

\section{Pendahuluan}

Perkembangan teknologi wireless internet telah berdampak pada pesatnya perkembangan teknologi perangkat mobile, terutama telepon seluler (Cruz et al., 2008). Perkembangan penggunaan telepon selulertersebut tentunya menjadi peluang tersendiri bagi berbagai industri, baik untuk ekspansi pasar, maupun untuk meningkatkan kualitas layanan. Sektor perbankan merupakan industri yang secara luas telah mengintegrasikan layanannya menggunakan teknologi mobile.

Layanan finansial yang ditawarkan bank kepada nasabah dan diakses menggunakan perangkat mobile dikenal dengan istilah "mobile banking"(Suoranta dan Mattila, 2004; Pousttchi dan Schurig, 2004).

Saat ini mobile banking telah menjadi saluran distribusi layanan perbankan dengan jangkauan terluas. Saluran distribusi layanan perbankan yang telah ada, seperti kantor cabang, Anjungan Tunai Mandiri (ATM), kerjasama dengan kantor POS, atau internet, tidak satupun yang mampu menjangkau konsumen sebagaimana yang dapat dilakukan melalui teknologi mobile (Krugel, 2007).

Penelitian yang dilakukan Laukkanen (2007), menunjukkan bahwa pengguna mobile banking menganggap layanan mobile banking meningkatkan efisiensi dan kenyamanan karena dapat digunakan di mana pun, memungkinkan penghematan waktu dan melakukan transaksi untuk kebutuhan yang tak terduga dan mendesak.

\footnotetext{
${ }^{1}$ Staf Pengajar IKIP Mataram

${ }^{2}$ Staf Pengajar FISIPOL Universitas Muhammadiyah Mataram

${ }^{3}$ Staf Pengajar Jurusan Manajemen FEB Universitas Mataram, adipermadiunram@gmail.com
} 
Dari sisi efisiensi biaya perbankan bagi konsumen, mobile banking memberi manfaat efisiensi yang sangat besar dengan memangkas biaya penyediaan layanan finansial kepada konsumen (Krugel, 2007). International Finance Corporation (IFC) menyebutkan, dengan layanan mobile bank dapat menekan biaya perbankan bagi konsumen sebesar 50 persen sampai 70 persen (http://www.infobanknews.com).

Meskipun informasi ketersediaan dan manfaat layanan mobile banking telah tersebar secara luas, namun analisis pasar menunjukkan masih rendahnya tingkat penggunaan layanan mobile banking (Kleijnen et al., 2007). Survei yang dilakukan Empaticha di Amerika dan Kanada pada 2010 menunjukkan kantor bank cabang terdekat masih menjadi pilihan utama nasabah dalam melakukan transaksi sebesar 76,2 persen dan 85,2 persen. Sedangkan layanan mobile banking menempati urutan pilihan terbawah dengan 1,7 persen di Amerika dan 1,1 persen di Kanada (http://www.vibiznews.com).

Rendahnya adopsi layanan mobile banking ditunjukkan pula oleh pasar di Indonesia seperti pengguna mobile banking BCA yang jumlahnya baru menyentuh angka 2,3 juta pengguna (rekening) atau sekitar 23,7 persen dari total 9,7 juta nasabah (rekening) BCA (http://finance.detik.com). Begitu juga dengan Bank Mandiri, dimana jumlah nasabah yang aktif menggunakan layanan mobile banking hanya berkisar 600 hingga 700 ribu dari 4 juta nasabah yang terdaftar pada layanan mobile banking (http://inet.detik.com) atau berkisar 5,5 hingga 6,4 persen saja.

Fenomena rendahnya tingkat adopsi suatu inovasi pada awal kemunculannya sebagaimana yang tampak pada fenomena layanan mobile banking di atas, disebut oleh Ram (1987) dengan istilah "resistance" (resistensi). Menurutnya, resistensiadalah respon yang normal dari konsumen terhadap inovasi sebelum mulai menerima atau mengadopsinya (Ram, 1987). Bahkan, menurut Sheth (1981), umumnya manusia memiliki kecenderungan untuk tidak berubah.

Ram (1987) berpendapat, resistensi konsumen terhadap suatu inovasi tidak berarti gagalnya inovasi tersebut, karena resistensi tidak terjadi hanya pada inovasi yang gagal, melainkan juga terjadi pada inovasi yang adopsinya berhasil. Meskipun respon adopsi dan resistensi bisa ada bersamaan, menurutnya, akan lebih tepat jika kajian ditujukan pada resistensi awal terhadap inovasi. Hal ini penting untuk mengatasi resistensi tersebut sebelum adopsi berhasil.

Karena itu, tepat jika kemudian Sheth (1981) menganjurkan untuk mengurangi penekanan dalam melihat inovasi dari perspektif adopsi dan penyebarannya, dan memberikan perhatian pada kajian terhadap proses resistensi inovasi. Maka, untuk mengurangi kemungkinan kegagalan inovasi, penting bagi manajer dan perusahaan secara umum untuk mengidentifikasi sumbersumber resistensi terhadap inovasi (Ram, 1989) dalam (Laukkanen dan Cruz, 2010:2). Selain untuk kepentingan dunia praktis, resistensi sebagai sebuah fenomena juga memiliki signifikansi akademik untuk dikaji, terutama untuk memahami resistensi terhadap inovasi dan alasan yang memperlambat proses adopsi.

Fenomena pesatnya perkembangan penggunaan telepon seluler dan kemudahan yang ditawarkan oleh layanan mobile banking di satu sisi, dan di sisi lain adanya resistensi terhadap mobile banking yang ditunjukkan oleh beberapa teori dan hasil penelitian, telah menarik perhatian peneliti untuk melakukan penelitian guna mengetahui dan menganalisis faktor-faktor yang berpengaruh terhadap resistensi inovasi mobile banking di Kota Mataram.

\section{Kajian Pustaka}

\subsection{Theory of Innovation Resistance}

Pada banyak pembahasan, istilah "resistensi" telah dikaitkan dengan inovasi teknologi, terutama kaitannya dengan respon konsumen terhadap inovasi teknologi. Menurut Ram (1987), resistensi merupakan respon normal konsumen terhadap suatu inovasi dan menjadi suatu hal yang harus 
dijalani sebelum teknologi tersebut diadopsi. Resistensi terhadap suatu inovasi terjadi baik pada inovasi yang berhasil maupun gagal.

Pendapat di atas dikuatkan oleh Kuisma et al. (2007) yang memperjelas konsep resistensi dengan membedakannya dari konsep penolakan (rejection). Jika "penolakan", menurutnya, adalah bentuk perilaku pasif yang menghasilkan keputusan akhir untuk tidak mengadopsi atau mengabaikan inovasi, maka "resistensi" merupakan perilaku aktif yang muncul pada setiap proses adopsi, namun tidak selalu menghasilkan penolakan terhadap inovasi (Kuisma et al., 2007).

Dalam mengembangkan pemahaman terhadap resistensi inovasi secara komprehensif, Ram dan Sheth (1989) mengajukan konsep resistance barriers yang terdiri dari functional barrier (kendala fungsional) dan psychological barrier (kendala psikologis) yang kemudian dikenal dengan theory of innovation resistance. Functional barrier (kendala fungsional) terbagi menjadi usage barrier (kendala penggunaan), value barrier (kendala nilai), dan risk barrier (kendala risiko), sementara psychological barrier (kendala psikologis) terdiri dari tradition barrier (kendala tradisi)dan image barrier (kendala citra).

Kendala penggunaan (usage barrier) terkait dengan ketidaksesuaian inovasi dengan kebiasaan konsumen. Karena preferensi konsumen pada kebiasaan dan produk yang ada, inovasi tentunya juga harus menawarkan nilai lebih dari sisi kemudahan penggunaan agar diadopsi (Ram dan Sheth, 1989).

Terkait dengan kendala nilai (value barrier), inovasi selain menawarkan nilai tambah dalam hal kinerja harus pula dapat menawarkan nilai tambah dalam hal harga. Jika tidak, maka produk pengganti yang akan dipilih oleh konsumen (Ram dan Sheth, 1989).

Risk barrier (kendala risiko) merujuk pada tingkat risiko yang dibawa oleh inovasi (Ram \& Sheth, 1989). Ketidakpastian dalam inovasi bersifat inheren, karena itu, inovasi selalu membawa kadar tertentu dari persepsi risiko. Risiko dapat bersifat fisik yang menyebabkan kerugian. Risiko juga dapat bersifat ekonomis, contohnya keputusan untuk segera mengadopsi inovasi dan tidak menunggu inovasi berikutnya yang ternyata lebih baik dan murah. Risiko juga dapat bersifat fungsional karena inovasi yang tidak dapat bekerja dengan benar. Selain itu, risiko juga dapat bersifat sosial, seperti dampak berupa kekhawatiran dipandang negatif oleh orang lain (Ram dan Sheth, 1989).

Tradition barrier (kendala tradisi) terutama merujuk pada perubahan inovasi yang berakibat pada rutinitas. Jika rutinitas tersebut penting bagi konsumen, maka resistensi cenderung tinggi.

Adapun image barrier (kendala citra), dikaitkan dengan asal inovasi seperti kelas produk dan merek perusahaan. Persepsi negatif atas kelas produk atau merek perusahaan juga dapat meningkatkan resistensi (Ram dan Sheth, 1989).

\subsection{Hipotesis}

Ram dan Sheth (1989) berpendapat bahwa usage barrier (kendala penggunaan) muncul ketika suatu inovasi tidak sesuai dengan cara kerja, praktik atau kebiasaan yang ada. Ini sesuai dengan konsep ease of use dalam Technologi Acceptance Model (TAM) oleh Davis et al. (1989) dalam Laukkanen (2008:2) yang diartikan dengan tingkat usaha yang minim untuk menggunakan suatu inovasi. Dalam konteks mobile banking, beberapa nasabahbank menganggap pembayaran tagihan melalui mobile banking sulit dan menghabiskan waktu karena perangkat telepon seluler hanya dapat memproses jumlah informasi yang terbatas sehingga tidak seluruh tagihan dapat terlihat (Laukkanen dan Lauronen, 2005 dalam Laukkanen, 2008:2). Berdasarkan pembahasan ini, dibuat hipotesis:

H1 : Usage barrier berpengaruh secara signifikan terhadap resistensi mobile banking. 
Brown et al. (2003), dalam Laukkanen (2008:2), menunjukkan bahwa semakin tinggi persepsi manfaat yang ditawarkan mobile banking dibanding layanan lain, semakin tinggi adopsi mobile banking. Namun, jika mobile banking tidak menawarkan keunggulan dibanding layanan alternatif, maka konsumen akan cenderung resisten dalam mengubah perilaku mereka (Ram dan Sheth, 1989). Untuk itu, dibuat hipotesis:

H2 : Value barrier berpengaruh secara signifikan terhadap resistensi mobile banking.

Risk barrier (kendala risiko) merujuk pada tingkat risiko yang dibawa oleh inovasi (Ram \& Sheth, 1989). Ketidakpastian dalam inovasi bersifat inheren, karena itu, inovasi selalu membawa kadar tertentu dari persepsi risiko. Selain itu, risiko juga dapat bersifat fisik yang menyebabkan kerugian. Risiko juga dapat bersifat fungsional karena inovasi yang tidak dapat bekerja dengan benar (Ram dan Sheth, 1989). Dalam konteks mobile banking, risiko yang dipersepsikan konsumen dapat berupa gagalnya transaksi perbankan karena kemungkinan menurunnya daya baterai atau koneksi seluler yang terputus. Selain itu, risiko keamanan menjadi isu penting bagi konsumen untuk menggunakan layanan mobile banking. Untuk itu, dibuat hipotesis:

H3 : Risk barrier berpengaruh secara signifikan terhadap resistensi mobile banking.

Tradition barrier (kendala tradisi) terutama merujuk pada perubahan inovasi yang berakibat pada rutinitas. Jika rutinitas tersebut penting bagi konsumen, maka resistensi cenderung tinggi. Dalam konteks mobile banking, kendala ini dapat muncul dari hasrat kuat nasabah untuk berinteraksi dengan pegawai teller (Marr dan Prendergast, 1993, dalam Laukkanen, 2008:3). Preferensi nasabah untuk berinteraksi dengan teller muncul dari kebutuhan interaksi sosial (Heinonen, 2004, dalam Laukkanen, 2008:3). Berdasarkan hal tersebut, dibuat hipotesis:

H4 : Tradition barrier berpengaruh secara signifikan terhadap resistensi mobile banking.

Adapun image barrier (kendala citra), dikaitkan dengan asal inovasi seperti kelas produk dan merek perusahaan. Persepsi negatif atas kelas produk atau merek perusahaan juga dapat meningkatkan resistensi (Ram dan Sheth, 1989). Dalam kasus mobile banking, persepsi rumitnya teknologi mobile banking bagi sebagian konsumen akan membentuk citra negatif mobile banking. Untuk itu, dibuat hipotesis:

H5 : Image barrier berpengaruh secara signifikan terhadap resistensi mobile banking.

Selain kendala-kendala resistensi yang diajukan Ram dan Sheth (1989) di atas, resistensi juga dilihat dari karakteristik demografi sebagaimana yang diteliti oleh Suoranta (2003), Kuisma et al. (2007), Laukkanen dan Pasanen (2008), Laukkanen dan Cruz (2010) Naseri dan Elliot (2011) dan Sorournejad (2011). Terkait inovasi teknologi, jenis kelamin merupakan karakteristik demografi yang paling banyak diteliti. Penelitian yang dilakukan Laukkanen dan Pasanen (2008), Laukkanen dan Cruz (2010) dan Sorournejad (2011) menunjukkan bahwa tingkat pengguna mobile banking dari laki-laki jauh lebih besar dibandingkan dengan perempuan. Untuk itu dibuat hipotesis:

H6 : Jenis kelamin berpengaruh secara signifikan terhadap resistensi mobile banking.

H7 : Usia berpengaruh secara signifikan terhadap resistensi mobile banking.

Naseri dan Elliot (2011) melalui penelitiannya menunjukkan bahwa tingkat penghasilan dan tingkat pendidikan berpengaruh terhadap transaksi online. Dalam hal adopsi mobile banking, penelitian yang dilakukan oleh Suoranta (2003) dan Sorournejad et al. (2011) menunjukkan adanya hubungan yang signifikan antara tingkat penghasilan dan tingkat pendidikan dengan resistensi mobile banking. Lebih lanjut, penelitian Meuter et al. (2005) dalam Laukkanen dan Cruz (2010:3) menunjukkan bahwa konsumen dengan tingkat pendidikan yang lebih tinggi memiliki persepsi yang rendah terhadap kerumitan inovasi tersebut.

H8 : Tingkat pendidikan berpengaruh secara signifikan terhadap resistensi mobile banking. 
H9 : Penghasilan berpengaruh secara signifikan terhadap resistensi mobile banking.

\section{Metode Penelitian}

Populasi penelitian ini adalah seluruh nasabah BRI, BCA, dan Bank Mandiri di Kota Mataram yang menggunakan telepon seluler dengan sample berjumlah 234 responden Pengumpulan data pada penelitian ini menggunakan kuesioner dengan teknik accidental sampling atau convinience sampling. Untuk mengukur variabel-variabel bebas usage barrier, value barrier, risk barrier, tradition barrier, dan image barrier digunakan instrumen dengan skala Likert 5 point yang dikembangkan dari instrumen yang digunakan oleh Laukkanen et al. (2007).

Teknik analisis data pada penelitian ini menggunakan regresi logistik biner(binary logistic regression). Regresi logistik biner digunakan untuk memodelkan hubungan antara variabel bebas dengan variabel terikat yang berupa data dengan ukuran biner/dikotomi. Variabel terikat penelitian ini adalah "resistensi mobile banking" yaitu status penggunaan layanan mobile banking dengan ukuran biner/dikotomi, 0 untuk "pengguna" dan 1 untuk "bukan pengguna".

\section{Hasil Penelitian}

Karakteristik demografi usia pada penelitian yang dilakukan oeh Laukkanen et al. (2007) juga menunjukkan pengaruh terhadap resistensi mobile banking, dimana konsumen dewasa (di atas 55 tahun) lebih resisten terhadap mobile banking dibandingkan dengan konsumen usia muda. Sedangkan penelitian yang dilakukan oleh Laukkanen dan Pasanen (2008) menunjukkan bahwa mayoritas pengguna mobile banking adalah konsumen yang berusia 30-49 tahun. Berdasarkan hal tersebut, dibuat hipotesis:

Pengaruh variabel bebas terhadap variabel terikat diuji dengan membandingkan $p$-value pada statistik Wald dengan tingkat signifkansi yang digunakan, yaitu sebesar 0,05. Kriteria penerimaan hipotesis adalah jika $p$-value $<0,05$ (Yamin et al., 2011:190). 
Tabel 1. Perhitungan Variabel

\begin{tabular}{|c|c|c|c|c|c|c|c|}
\hline & & B & S.E. & Wald & $\mathrm{df}$ & Sig. & $\operatorname{Exp}(B)$ \\
\hline \multirow[t]{19}{*}{ Step $1^{a}$} & Usage & .844 & .416 & 4.110 & 1 & .043 & 2.326 \\
\hline & Value & .993 & .395 & 6.335 & 1 & .012 & 2.699 \\
\hline & Risk & .907 & .381 & 5.676 & 1 & .017 & 2.476 \\
\hline & Tradition & -.130 & .425 & .094 & 1 & .759 & .878 \\
\hline & Image & .380 & .362 & 1.104 & 1 & .293 & 1.463 \\
\hline & Kelamin(1) & 1.277 & .572 & 4.988 & 1 & .026 & 3.587 \\
\hline & Usia & & & 9.785 & 4 & .044 & \\
\hline & Usia(1) & .986 & .619 & 2.535 & 1 & .111 & 2.680 \\
\hline & Usia(2) & 2.542 & 1.499 & 2.876 & 1 & .090 & 12.710 \\
\hline & Usia(3) & 2.265 & .783 & 8.370 & 1 & .004 & 9.636 \\
\hline & Usia(4) & 4.473 & 1.857 & 5.799 & 1 & .016 & 87.612 \\
\hline & Pendidikan & & & 4.422 & 3 & .219 & \\
\hline & Pendidikan(1) & .498 & 1.799 & .077 & 1 & .782 & 1.646 \\
\hline & Pendidikan(2) & -.085 & .885 & .009 & 1 & .923 & .918 \\
\hline & Pendidikan(3) & -1.773 & 1.649 & 1.156 & 1 & .282 & .170 \\
\hline & Penghasilan & & & 2.802 & 2 & .246 & \\
\hline & Penghasilan(1) & -1.308 & .822 & 2.533 & 1 & .112 & .270 \\
\hline & Penghasilan(2) & -1.643 & 1.227 & 1.792 & 1 & .181 & .193 \\
\hline & Constant & -11.088 & 2.847 & 15.169 & 1 & .000 & .000 \\
\hline
\end{tabular}

a. Variable(s) entered on step 1: Usage, Value, Risk, Tradition, Image, Kelamin, Usia, Pendidikan, Penghasilan.

\section{Uji Hipotesis 1: Pengaruh UsageBarrier terhadap Resistensi Inovasi Mobile Banking}

Dari nilai statistik Wald diketahui p-value untuk variabel usage barrier adalah 0,043. Berdasarkan kriteria uji hipotesis, karena $p$-value $<0,05$ maka hipotesis yang menyatakan "usage barrier berpengaruh secara signifikan terhadap resistensi mobile banking" dinyatakan diterima.

Berdasarkan nilai odd ratio $>1$ yaitu 2,326 maka dapat dinyatakan: "jika variabel usage barrier meningkat, maka peluang terbentuknya resistensi inovasi mobile banking akan meningkat sebesar 2,326 kali dimana variabel bebas lainnya dalam keadaan konstan."

Hasil ini sesuai dengan teori yang dikemukakan oleh Ram dan Sheth (1989) bahwa usage barrier muncul karena ketidaksesuaian inovasi dengan kebiasaan konsumen dalam menggunakan layanan yang telah ada. Hasil ini menunjukkan bahwa persepsi responden terhadap kesulitan penggunaan, lambatnya penggunaan, dan ketidaknyamanan penggunaan layanan menjadi faktor yang signifikan mempengaruhi responden untuk mengadopsi mobile banking atau tidak.

Selain itu, hasil ini mendukung penelitian yang dilakukan oleh Laukkanen dan Lauronen (2005) dalam (Laukkanen, 2008:2). Bahkan penelitian yang dilakukan oleh Cruz et al. (2008) dan Laukkanen (2008) menunjukkan bahwa usage barrier merupakan kendala yang paling berpengaruh terhadap resistensi inovasi mobile banking.

\section{Uji Hipotesis 2: Pengaruh ValueBarrier terhadap Resistensi Inovasi Mobile Banking}

Dari nilai statistik Wald diketahui $p$-value untuk variabel value barrier adalah 0,012. Berdasarkan kriteria uji hipotesis, karena p-value $<0,05$ maka hipotesis yang menyatakan "value barrier berpengaruh secara signifikan terhadap resistensi inovasi mobile banking" dinyatakan diterima. 
Sedangkan berdasarkan nilai odd ratio $>1$ yaitu 2,669 maka dapat dinyatakan: "jika variabel value barrier meningkat, maka peluang terbentuknya non-adopsi mobile banking akan meningkat sebesar 2,669 kali dimana variabel bebas lainnya dalam keadaan konstan."

Dengan nilai $p$-value sebesar 0,012 variabel value barrier pada penelitian ini merupakan kendala yang paling berpengaruh terhadap resistensi inovasi mobile banking. Hasil ini sesuai dengan hasil penelitian yang dilakukan oleh Laukkanen et al. (2007).

Terkait hasil pengujian variabel value barrier tersebut,Ram dan Sheth (1989) berpendapat bahwa inovasi selain menawarkan nilai tambah dalam hal kinerja harus pula dapat menawarkan nilai tambah dalam hal harga. Jika tidak, maka produk pengganti yang akan dipilih oleh konsumen. Hasil ini menunjukkan bahwa persepsi responden terhadap nilai ekonomis dan keunggulan mobile banking dibandingkan layanan perbankan lainnya, menjadi faktor yang paling signifikan mempengaruhi responden untuk mengadopsi mobile banking atau tidak.

\section{Uji Hipotesis 3: Pengaruh RiskBarrier terhadap Resistensi Inovasi Mobile Banking}

Dari nilai statistik Wald diketahui $p$-value untuk variabel risk barrier adalah 0,017. Berdasarkan kriteria uji hipotesis, karena p-value < 0,05 maka hipotesis yang menyatakan "risk barrier berpengaruh secara signifikan terhadap resistensi mobile banking" dinyatakan diterima.

Berdasarkan nilai odd ratio $>1$ yaitu 2,476 maka dapat dinyatakan: "jika variabel risk barrier meningkat, maka peluang terbentuknya non-adopsi mobile banking akan meningkat sebesar 2,476 kali dimana variabel bebas lainnya dalam keadaan konstan."

Hasil uji hipotesis terhadap variabel risk barrier ini mendukung teori yang dinyatakan oleh Ram dan Sheth (1989) bahwa ketidakpastian dalam inovasi bersifat inheren, karena itu, inovasi selalu membawa kadar tertentu dari persepsi risiko. Dalam konteks mobile banking, risiko yang dipersepsikan konsumen dapat berupa gagalnya transaksi perbankan karena kemungkinan menurunnya daya baterai atau koneksi seluler yang terputus. Selain itu, risiko keamanan menjadi isu penting bagi konsumen untuk menggunakan layanan mobile banking.

\section{Uji Hipotesis 4: Pengaruh TraditionBarrier terhadap Resistensi Inovasi Mobile Banking}

Dari nilai statistik Wald diketahui p-value untuk variabel tradition barrier adalah 0,795. Berdasarkan kriteria uji hipotesis, karena $p$-value $>0,05$ maka hipotesis yang menyatakan "tradition barrier berpengaruh secara signifikan terhadap resistensi mobile banking" dinyatakan ditolak.

Hasil ini tidak sesuai dengan hasil penelitian yang dilakukan oleh Heinonen (2004) dalam (Laukkanen, 2008:3) yang menunjukkan bahwa nasabah memiliki preferensi untuk berinteraksi dengan teller sebagai bentuk dari kebutuhan interaksi sosial. Namun, hasil yang sama dengan penelitian ini ditunjukkan oleh penelitian yang dilakukan Cruz et al. (2008).

Menurut Ram dan Sheth (1989), tradition barrier terutama merujuk pada perubahan inovasi yang berakibat pada rutinitas. Jika rutinitas tersebut penting bagi konsumen, maka resistensi cenderung tinggi. Berdasarkan pendapat tersebut, dalam kaitannya dengan layanan mobile banking hasil penelitian ini menunjukkan bahwa transaksi dengan tatap muka, bukti transaksi tercetak, ataupun tradisi berinteraksi dengan petugas layanan saat transaksi tidak mempengaruhi kemungkinan responden untuk menggunakan layanan mobile banking atau tidak. Hal ini sangat mungkin karena berbagai produk dan layanan, baik yang ditawarkan sektor perbankan seperti ATM, Kartu Kredit, Kartu Debet, dan Internet Banking; maupun yang ditawarkan dunia usaha berkerjasama dengan sektor perbankan seperti e-commerce telah menggeser pola transaksi konvensional nasabah.

\section{Uji Hipotesis 5: Pengaruh ImageBarrier terhadap Resistensi Inovasi Mobile Banking}


Dari nilai statistik Wald diketahui p-value untuk variabel image barrier adalah 0,293. Berdasarkan kriteria uji hipotesis, karena $p$-value $>0,05$ maka hipotesis yang menyatakan "image barrier berpengaruh secara signifikan terhadap resistensi mobile banking" dinyatakan ditolak.

Hasil ini tidak sesuai dengan hasil penelitian yang dilakukan oleh Laukkanen et al. (2007). Pada teori yang dikemukakan oleh Ram dan Sheth (1989), image barrier dikaitkan dengan asal inovasi seperti kelas produk dan merek perusahaan. Persepsi negatif atas kelas produk atau merek perusahaan juga dapat meningkatkan resistensi.

Hasil ini mengimplikasikan bahwa dalam kaitannya dengan keputusan untuk menggunakan layanan atau tidak, persepsi positif responden terhadap penggunaan dan nilai tambah layanan mobile banking dapat mengatasi persepsi negatif responden terhadap citra layanan.

\section{Uji Hipotesis 6: Pengaruh Jenis Kelamin terhadap Resistensi Inovasi Mobile Banking}

Pada uji hipotesis untuk variabel faktor demografi dengan kategori jenis kelamin, kelompok laki-laki dijadikan sebagai kategori rujukan (reference category) yang diperbandingkan dengan kelompok perempuan (JK[1]).

Dari nilai statistik Wald diketahui p-value untuk jenis kelaminadalah 0,026. Berdasarkan kriteria uji hipotesis, karena p-value < 0,05 maka hipotesis yang menyatakan "jenis kelaminberpengaruh secara signifikan terhadap resistensi mobile banking" dinyatakan diterima.

Berdasarkan nilai odd ratio untuk jenis kelamin perempuan (JK[1]) sebesar 3,587 maka dapat dinyatakan: "kemungkinan kelompok perempuan untuk non-adopsi mobile banking lebih tinggi sebesar 3,587 kali dibandingkan kelompok laki-laki dimana variabel bebas lainnya dalam keadaan konstan".

Hasil uji hipotesis untuk variabel kategori jenis kelamin pada penelitian ini sesuai dengan hasil beberapa penelitian yang menunjukkan bahwa tingkat pengguna mobile banking laki-lakijauh lebih besar dibandingkan dengan perempuan (Laukkanen and Pasanen, 2008; Laukkanen dan Cruz, 2010; Sorournejad, 2011).

Tidak sebatas pada penelitian mengenai mobile banking, pada penelitian yang dilakukan Garbarino dan Strahilevitz (2004) untuk mengetahui perbedaan laki-laki dan perempuan pada penggunaan layanan online menunjukkan bahwa dibandingkan dengan perempuan, laki-laki memiliki persepsi risiko yang rendah dalam menggunakan layanan online untuk aktivitas bisnis mereka.

\section{Uji Hipotesis 7: Pengaruh Usia terhadap Resistensi Inovasi MobileBanking}

Pada uji hipotesis untuk variabel kategori usia, kelompok usia di bawah 20 tahun dijadikan sebagai kategori rujukan (reference category) yang diperbandingkan dengan kelompok usia lain, yaitu: usia 20 - 29 tahun (Usia[1]), usia 30 - 39 tahun (Usia[2]), usia 40 - 49 tahun (Usia[3]), dan Usia $\geq 50$ (Usia[5]).

Dari nilai statistik Wald diketahui $p$-value untuk variabel faktor demografi dengan kategori usia secara keseluruhan adalah 0,044. Berdasarkan kriteria uji hipotesis, karena $p$-value $<0,05$ maka hipotesis yang menyatakan "usiaberpengaruh secara signifikan terhadap resistensi mobile banking" dinyatakan diterima.

Karena kelompok dalam kategori usia lebih dari dua, maka selain uji hipotesis untuk melihat pengaruh variabel usia secara umum terhadap resistensi inovasi mobile banking, juga dianalisis signifikansi perbedaan peluang (odds ratio)antara kelompok usia di bawah 20 tahun sebagai kategori rujukan (reference category) dengan kelompok usia lainnya.

Berdasarkan hasil analisis regresi logistik, diketahui bahwa p-value kelompok usia $20-29$ tahun (usia[1]) adalah 0,111. Nilai ini lebih besar dari kriteria tingkat signifikansi sebesar 0,05 sehingga dapat dinyatakan bahwa tidak terdapat perbedaan peluang (odds ratio) yang signifikan antara kelompok usia 20 - 29 tahun dengan kelompok usia di bawah 20 tahun. Demikian pula dengan kelompok usia 30 - 39 tahun (usia[2]) dengan nilai p-value 0,090yang lebih besar dari 0,005. 
Sedangkan kelompok usia lainnya memiliki nilai p-value yang lebih kecil dari 0,05 sehingga dapat dinyatakan bahwa terdapat perbedaan peluang (odds ratio) yang signifikan antara kelompok usia 40 - 49 tahun (usia[3]) dan usia di atas 50 tahun (usia[4]) dengan kelompok usia di bawah 20 tahun.

Kelompok usia 40 - 49 tahun (Usia[3]) memiliki nilai odd ratio sebesar 9,636 sehingga dapat dinyatakan: "kemungkinan kelompok usia 40 - 49 tahun untuk non-adopsi mobile banking lebih tinggi sebesar 9,636 kali dibandingkan kelompok usia di bawah 20 tahun dimana variabel bebas lainnya dalam keadaan konstan".

Sedangkan dengan nilai odd ratio sebesar 87,612 pada kelompok usia di atas 50 tahun (Usia[4]) dapat dinyatakan: "kemungkinan kelompok usia di atas 50 tahun untuk non-adopsi mobile banking lebih tinggi sebesar 87,612 kali dibandingkan kelompok usia di bawah 20 tahun dimana variabel bebas lainnya dalam keadaan konstan".

Hasil uji hipotesis pada penelitian ini menguatkan penelitian yang dilakukan oeh Laukkanen et al. (2007) yang menunjukkan bahwa konsumen dewasa (di atas 55 tahun) lebih resisten terhadap mobile banking dibandingkan dengan konsumen usia muda. Namun, hasil ini berbeda dengan hasil penelitian yang dilakukan oleh Laukkanen dan Cruz (2010) yang menunjukkan bahwa usia tidak memiliki pengaruh signifikan terhadap resistensi mobile banking.

\section{Uji Hipotesis 8: Pengaruh Tingkat Pendidikan terhadap Resistensi Inovasi Mobile Banking}

Dari nilai statistik Wald diketahui p-value untuk variabel faktor demografi dengan kategori tingkat pendidikan adalah 0,219. Berdasarkan kriteria uji hipotesis, karena $p$-value $>0,05$ maka hipotesis yang menyatakan "tingkat pendidikan berpengaruh secara signifikan terhadap resistensi mobile banking" dinyatakan ditolak.

Hasil ini sesuai dengan hasil penelitian yang dilakukan oleh Laukkanen dan Cruz (2010), namun berbeda dengan hasil beberapa penelitian lainnya.Penelitian Meuter et al. (2005) dalam Laukkanen dan Cruz (2010:3-4) menunjukkan bahwa konsumen dengan tingkat pendidikan yang lebih tinggi memiliki persepsi yang rendah terhadap kerumitan inovasi tersebut. Dalam hal adopsi mobile banking, penelitian yang dilakukan oleh Suoranta (2003) dan Sorournejad et al. (2011) menunjukkan adanya hubungan yang signifikan antara tingkat pendidikan dengan resistensi mobile banking. Sedangkan penelitian mengenai hubungan tingkat pendidikan dengan inovasi lainnya adalah yang dilakukan oleh Naseri dan Elliot (2011) yang menunjukkan bahwa tingkat pendidikan berpengaruh terhadap transaksi online.

Hasil yang tidak signifikan ini mengimplikasikan bahwa pengaruh yang diberikan oleh tingkat pendidikan terutama terkait dengan wawasan lebih luas yang umumnya dimiliki oleh orang-orang dengan tingkat pendidikan yang lebih tinggi. Wawasan tersebut yang kemudian dapat mendorong orang untuk lebih adaptif terhadap perubahan. Kaitannya dengan layanan mobile banking, hasil ini menunjukkan bahwa wawasan yang dimiliki oleh nasabah lebih dipengaruhi oleh faktor-faktor seperti: sejauhmana informasi terkait layanan yang disediakan oleh bank dan sumber-sumber informasi lain yang relatif mudah diakses oleh masyarakat umum (seperti tv, internet, dll.), sehingga tingkat pendidikan menjadi tidak signfikan. Dengan asumsi ini, sangat mungkin hasil penelitian-penelitian berikutnya akan menunjukkan hasil yang sama.

\section{Uji Hipotesis 9: Pengaruh Penghasilan terhadap Resistensi Inovasi Mobile Banking}

Dari nilai statistik Wald diketahui $p$-value untuk variabel faktor demografi dengan kategori penghasilan adalah 0,246. Berdasarkan kriteria uji hipotesis, karena $p$-value $>0,05$ maka hipotesis yang menyatakan "penghasilan berpengaruh secara signifikan terhadap resistensi mobile banking" dinyatakan ditolak.

Hasil ini sesuai dengan hasil penelitian yang dilakukan oleh Laukkanen dan Cruz (2010), namun berbeda dengan hasil beberapa penelitian lainnya.Dalam hal adopsi mobile banking, penelitian yang dilakukan oleh Suoranta (2003) dan Sorournejad et al. (2011) menunjukkan adanya 
hubungan yang signifikan antara tingkat penghasilan dengan resistensi mobile banking. Sedangkan penelitian yang dilakukan oleh Naseri dan Elliot (2011) yang menunjukkan bahwa tingkat penghasilan berpengaruh terhadap transaksi online.

Kadusic et al. (2011) menjelaskan bahwa penghasilan mempengaruhi daya beli dan juga kebiasaan konsumsi. Hal ini dipertegas oleh pernyataan Burroughs dan Sabherwal (2002) dalam (Nasri dan Elliot, 2011:72) bahwa keterjangkauan (affordability) merupakan salah satu faktor mengapa orang dengan tingkat penghasilan lebih tinggi lebih menerima suatu inovasi.

Selain itu, penghasilan dapat menjadi signifikan jika penerimaan terhadap suatu inovasi dikaitkan dengan risiko finansial, sebagaimana yang dinyatakan oleh Dickerson dan Gentry, (1983) dalam Nasri dan Elliot (2011: 72) bahwa risiko finansial suatu adopsi lebih tinggi dirasakan oleh masyarakat berpenghasilan rendah.

Pendapat-pendapat di atas secara tidak langsung dapat menjelaskan mengapa hasil uji hipotesis ini menunjukkan hasil yang tidak signifikan. Pertama, untuk mengadopsi layanan mobile banking yang dibutuhkan adalah perangkat telepon seluler. Sedangkan saat ini, terdapat beragam jenis perangkat mobile, terutama telepon seluler dengan berbagai spesifikasi dan fitur produk yang membuat harga produk juga menjadi sangat beragam. Beragamnya harga produk mempengaruhi daya beli masyarakat. Sehingga penghasilan masyarakat bukanlah suatu hal yang dapat memunculkan resistensi terhadap inovasi mobile banking.

Kedua, fitur-fitur layanan mobile banking memungkinkan dilakukannya transaksi keuangan yang tidak selalu bernilai tinggi. Bahkan pembelian pulsa yang menjadi kebutuhan standar pengguna telepon seluler dapat dilakukan dengan layanan mobile banking.

Ketiga, dengan munculnya isu-isu kejahatan dunia maya (cyber crime) dalam bentuk pembobolan rekening nasabah, bahkan sebaliknya dapat menjadi kendala risiko keuangan yang lebih tinggi dipersepsikan oleh nasabah dengan penghasilan tinggi.

Beberapa alasan di atas menjelaskan mengapa faktor penghasilan tidak berpengaruh signifikan terhadap resistensi inovasi mobile banking.

\section{Kesimpulan dan Saran}

\subsection{Kesimpulan}

Berdasarkan hasil penelitian dan pembahasan, maka disusunlah kesimpulan berikut:

1) Variabel usage barrier berpengaruh secara signifikan terhadap resistensi inovasi mobile banking dengan nilai signifikansi sebesar 0,43 .

2) Variabel value barrier berpengaruh secara signifikan terhadap resistensi inovasi mobile banking dengan nilai signifikansi sebesar 0,12.

3) Variabel risk barrier berpengaruh secara signifikan terhadap resistensi inovasi mobile banking dengan nilai signifikansi sebesar 0,17.

4) Variabel tradition barrier tidak berpengaruh secara signifikan terhadap resistensi inovasi mobile banking karena memiliki nilai signifikansi yang lebih besar dari 0,05 yaitu sebesar 0,759.

5) Variabel image barrier tidak berpengaruh secara signifikan terhadap resistensi inovasi mobile banking karena memiliki nilai signifikansi yang lebih besar dari 0,05 yaitu sebesar 0,293.

6) Variabel jenis kelaminberpengaruh secara signifikan terhadap resistensi inovasi mobile banking dengan nilai signifikansi sebesar 0,026 .

7) Variabel usia berpengaruh secara signifikan terhadap resistensi inovasi mobile banking dengan nilai signifikansi sebesar 0,044 .

8) Variabel tingkat pendidikan tidak berpengaruh secara signifikan terhadap resistensi inovasi mobile banking karena memiliki nilai signifikansi yang lebih besar dari 0,05 yaitu sebesar 0,219.

9) Variabel penghasilan tidak berpengaruh secara signifikan terhadap resistensi inovasi mobile banking karena memiliki nilai signifikansi yang lebih besar dari 0,05 yaitu sebesar 0,246. 


\subsection{Saran}

Berdasarkan hasil penelitian yang telah disimpulkan di atas, maka diajukan saran-saran, terutama bagi penyedia layanan mobile banking dan peneliti selanjutnya sebagai berikut:

1) Penyedia layanan mobile banking perlu melihat peluang bahwa terdapat kecenderungan pada masyarakat berupa melemahnya tradisi transaksi keuangan konvensional yang harus dilakukan dengan bertatap muka atau dengan bukti transaksi tercetak. Jika penyedia layanan mobile banking dapat mengatasi kendala-kendala penggunaan, nilai, dan risiko, maka layanan mobile banking memiliki potensi yang sangat besar sebagai nilai tambah (added value) yang dapat ditawarkan oleh sektor perbankan kepada nasabah dengan cara bekerjasama dengan operator seluler dan mitra penjual (merchants).

2) Penyedia layanan mobile banking perlu memperhatikan bahwa karakteristik demografi penghasilan yang tidak berpengaruh signifikan terhadap resistensi inovasi mobile banking menjadi satu indikasi bahwa penyedia layanan mobile banking tidak hanya perlu melakukan penetrasi pasar pada segmen berpenghasilan tinggi, melainkan juga segmen pasar berpenghasilan menengah yang merupakan pasar potensial di Indonesia.

3) Peneliti yang ingin meneliti layanan mobile banking lebih jauh, perlu melibatkan berbagai faktor di luar variabel resistance barrier dan faktor demografi, seperti: pengalaman bertransaksi elektronis dan tipe telepon seluler yang digunakan.

4) Peneliti berikutnya perlu mempertimbangkan perbedaan berbagai jenis layanan mobile banking untuk mengetahui respon masyarakat terhadap layanan mobile banking.

\section{Daftar Pustaka}

Cruz, P., Laukkanen, T., Munoz, P., (2008), "Effect of Demographic and Usage variables on M-Banking Resistance" makalah ini disampaikan pada Australian and New Zealand Marketing Academy (ANZMAC) Conference 2010. "Marketing: Shifting the Focus from Mainstream to Offbeat", Sydney, Australia, 1-3 Dec 2008.

Dickerson, M.D. and Gentry, J.W. (1983) Characteristics of Adopters and Non-Adopters Of Home Computers. Journal of Consumer Research10: 225-235.

Garbarino, E. \& Strahilevitz, M. (2004), "Gender differences in the perceived risk of buying online and the effects of receiving a site recommendation", Journal of Business Research, 57, 768-775.

Kadusic, E., Bojovic, P., Zgalj, A. (2011), “Consumer Adoption - Risk Factor of Mobile Banking Services", World Academy of Science, Engineering and Technology, 80, 136-141.

Kleijnen, M., Ruyter, K., \& Wetzels, M. (2007), “An Assessment of Value Creation in Mobile Service Delivery and The Moderating Role of Time Consciousness", Journal of Retailing, 83 (1), 33-46.

Krugel, G.T. (2007), Mobile Banking Technology Option, Johannerburg: FinMark Trust.

Kuisma, T., Laukkanena, L., Hiltunen, M. (2007), “Mapping the reasons for resistance to Internet banking: A means-end approach", International Journal of Information Management, XXVII,7585

Laukkanen, T. (2008), "Determinants of Mobile Banking Resistance: A Preliminary Model", makalah disampaikan pada Australian and New Zealand Marketing Academy Conference 2008, "Marketing: Shifting the Focus from Mainstream to Offbeat", Sydney Australia, 1-3 Dec.

Laukkanen, T., \& Cruz, P. (2010), “What Determines Mobile Banking Non-Adoption?" makalah disampaikan pada Australian and New Zealand Marketing Academy (ANZMAC) Conference 2010. “Doing More with Less”. Christchurch, New Zealand, 29 Nov-1 Dec 2010.

Laukkanen, T., \& Pasanen, M. (2008), "Mobile banking innovators and early adopters: How they differ from other online users?" Journal of Financial Services Marketing, XIII(2), 86-94. 
Naseri, M.B., \& Elliot, G. (2011), “Role of demographics, social connectedness and prior internet experience in adoption of online shopping: Applications for direct marketing", Journal of Targeting, Measurement and Analysis for Marketing, XIX (2), 69-84.

Pousttchi, K. \& Schurig, M. (2004), “Assessment of Today's Mobile Banking Applications from The View of Customer Requirements" makalah disampaikan pada The 37th Hawaii International Conference on System Sciences, Big Island, Hawaii, 5-8 Januari 2004.

Ram, S. (1987), "A Model of Innovation Resistance”, Advances in Consumer ResearchXIV, 208-212.

Ram, S., \& Sheth, J.N. (1989), “Consumer Resistance to Innovations: The Marketing Problem and Its Solutions", The Journal of Consumer Marketing, VI (2), 5-14.

Sheth. J.N. (1981), "Psychology of Innovation Resistance: The Less Developed Concept (LDC) in Diffusion Research", Research in Marketing, IV, 273-282.

Sorournejad, S., Monadjemi, A., Kharazian, M.A. (2011), "Resistance of mobile payment Iranian perspective", 2011 International Conference on Economics and Finance Research, IV, 395-398.

Suoranta, M. \& Mattila, M. (2004), “Mobile Banking and Consumer Behaviour: New Insights into The Diffusion Pattern", Journal of Financial Services Marketing, VIII (4), 354-366.

Suoranta, M. (2003), "Adoption of Mobile Banking in Finland", Disertasi, University of Jyvaskyla.

Yamin, S., Rachmach, L.A., Kurniawan, H. (2011), Regresi dan Korelasi dalam Genggaman Anda: Aplikasi dengan Software SPSS, EViews, MINITAB, dan STATGRAPHICS, Jakarta: Salemba Empat.

http:/ finance.detik.com/read/2011/10/12/112513/1742168/5/bca-genjot-pengguna-mobilebanking (Diakses 4 Mei 2012).

http:/ /inet.detik.com/read/2011/11/28/153247/1777353/398/e-banking-vs-m-banking-lebihpopuler-mana?i991102105 (Diakses 4 Mei 2012).

http:/ / www.infobanknews.com/2011/11/ifc-mobile-banking-bisa-tekan-biaya-operasionalbank/, (Diakses 14 April 2012).

http://www.vibiznews.com/news/banking_insurance/2010/10/08/survei-terbaru-mengenaiinternet-banking-dan-mobile-banking/our_link.php, (Diakses 14 April 2012). 